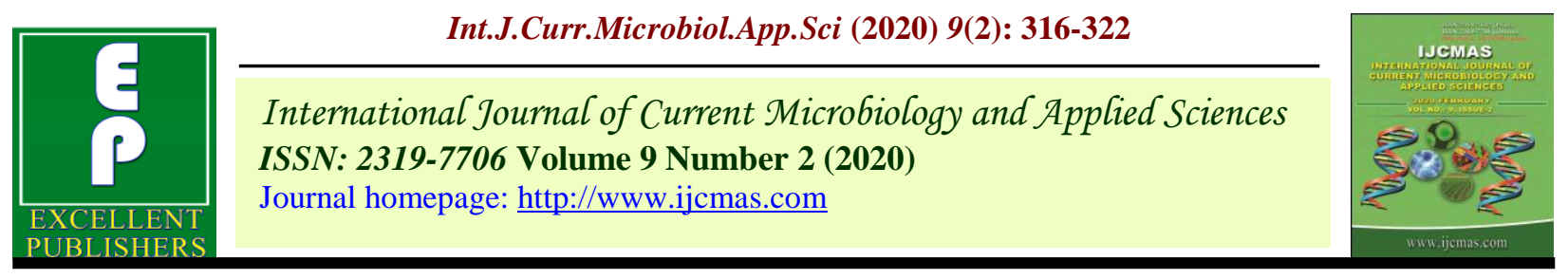

Original Research Article

https://doi.org/10.20546/ijcmas.2020.902.040

\title{
A Study on Socio-Economic Status and Problems faced by Camel Rearers in Rajasthan State of India
}

\author{
Gurbir Singh $^{1}$, Amita Sharma ${ }^{2}$ and Raghvendar Singh ${ }^{3}$ \\ ${ }^{1}$ IDP Cell, Guru Angad Dev Veterinaryand Animal Sciences University, \\ Ludhiana (141004), India \\ ${ }_{2}^{2}$ Institute of Agri-Business Management, Swami Keshwanand Rajasthan Agricultural \\ University, Bikaner (334006), India \\ ${ }^{3}$ ICAR-Central Sheep \& Wool Research Institute, Avikanagar (Malpura), District-Tonk \\ Rajasthan (304501), India, \\ *Corresponding author
}

\section{A B S T R A C T}

\section{Keywords}

Camel Milk, Socioeconomic status, Camel rearers

\section{Article Info}

Accepted:

05 January 2020

Available Online:

10 February 2020
India ranks tenth in the world with 0.38 million camel population. In November 2016, the Food Safety and Standards Authority of India (FSSAI) had approved camel milk for sale purpose. Camel milk is rich in minerals like Iron (0.32-0.36 $\mathrm{mg} / \mathrm{dl})$, Zinc $(1.2-6.3 \mathrm{mg} / \mathrm{dl})$, Copper $(0.09-0.5 \mathrm{mg} / \mathrm{dl})$ and Vitamins B1 (0.03 $\mathrm{mg} \%)$, Vitamin B6 (0.05 mg\%), Vitamin B12 (0.0002 mg\%) and Vitamin C (40$50 \mathrm{mg} / \mathrm{kg}$ ). Camel milk acts as immunomodulator due to presence of high amount of lysozyme, lactoferrin, immunoglobulins, lactoperoxidase and helpful in management of type 1 diabetes due to presence of insulin and insulin like protein (45-128 unit/litre). The study analysed the socio-economic status of 200 camel rearers in the State of Rajasthan in tabular form and identify the various problem faced by camel rearers in camel rearing using Rank Based Quotient technique. The most severe problem was no organized market for selling the produce followed by lengthy procedures for getting credit from government institutions for marketing purpose. The study revealed that with addressing these issues the camel rearers get benefitted from the present situation.

\section{Introduction}

Camel milk is white opaque in colour and without odour and has $8-11 \%$ total solids, $2.5 \%$ total protein but less fat $1-3 \%$. The shelflife of camel milk is up to 8-9 hours; further this can be extended up to $18-20$ hours at $37^{\circ} \mathrm{C}$ by activation of camel lactoperoxidase system. It is rich in minerals like Iron $(0.32-$ $0.36 \mathrm{mg} / \mathrm{dl})$, Zinc $(1.2-6.3 \mathrm{mg} / \mathrm{dl})$, Copper $(0.09-0.5 \mathrm{mg} / \mathrm{dl})$ and Vitamins B1 $(0.03$ $\mathrm{mg} \%)$, Vitamin B6 (0.05 mg\%), Vitamin B12 $(0.0002 \mathrm{mg} \%)$ and Vitamin C $(40-50 \mathrm{mg} / \mathrm{kg})$. Essential fatty acids (linoleic, arachidic etc.) are available in adequate quantity. Camel milk acts as immunomodulator due to 
presence of high amount of lysozyme, lactoferrin, immunoglobulins and lactoperoxidase. Camel milk is helpful in management of type 1 diabetes due to presence of insulin and insulin like protein (45-128 unit/litre).

It helps in management of tuberculosis, hepatitis-C and general skin infections. It is helpful for children having milk allergy with cow milk. Initial research findings prove its role in treatment of autism in children. It is effective in arthritis, cancer like disease and hypercholesterolemia. Fermented camel milk is effective as probiotic in the conditions of diarrhea, allergy and respiratory diseases

The term socio-economic broadly refers to 'use of economics in the study of society'. These are factors that influence how a particular group or socio-economic class, act within society including their actions as consumers.

Different socio-economic classes may have varying priorities regarding how they direct their funds. These characteristics can include social and economic standing, as well as other factors such as level of education, ethnic background or heritage, and most other ways individuals can be categorized.

\section{Materials and Methods}

The present study has relied on both qualitative and quantitative analysis of data. In addition to the data collected through interview schedule, the field notes and personal observations have been used in the data analysis.

The data is collected in camel milk potential area of Rajasthan sample contains 200 camel rearers. Socio-economic aspects such as social classes, family type, education, occupation, material possessions, housing, cooking fuel, annual income, camel milk production, camel milk marketing, benefits, social participation, savings instrument, problems faced by camel rearers are recorded through schedule.

Primary data were collected throughmeans of a structured comprehensive schedule from the camel rearers. Secondary data have been collected from the Ministry of Agriculture, Department of Animal Husbandry, Dairying, and Fisheries, a report published thesis work, unpublished thesis works, websites and research articles from journals.

\section{Objective 1: To study Socio-Economic Status of Camel Rearers}

The objective has aimed to study the SocioEconomic Status of 200 camel rearers in the State of Rajasthan in India. The data represented in frequency in a tabular formation.

\section{Objective 2: Identification of majorconstraints faced by Camel Rearers}

It has aimed to identify the various problem faced by camel rearers in camel rearing. An ordinal scale was used to collect response from camel rearers and Rank Based Quotient technique was applied to rank variables. This was showing the rank according to its prevalence and extent of a rank. The following formulawas used in the calculation

$$
R B Q=\frac{\sum_{i=1}^{n} f i(n+1-i)}{N \times n} \times 100
$$

Where,

$\mathrm{RBQ}=$ Rank Based Quotient

fi $=$ Number of respondents reporting a particular factor under $\mathrm{i}^{\text {th }}$ rank

$\mathrm{N}=$ Total number of respondents

$\mathrm{n}=$ Number of factors

$\mathrm{i}=$ concerned rank 
Table.1 Socio-economic aspectsof Camel Rearers

\begin{tabular}{|c|c|c|c|}
\hline Social Classes & Frequency & Percent & Total \\
\hline Raika & 31 & 15.5 & 200 \\
\hline Dewasi & 57 & 28.5 & 200 \\
\hline Rebari & 71 & 35.5 & 200 \\
\hline Bishnoi & 10 & 5.0 & 200 \\
\hline Muslim & 31 & 15.5 & 200 \\
\hline \multicolumn{4}{|l|}{ Family Type } \\
\hline Nuclear & 8 & 4.0 & 200 \\
\hline Joint & 192 & 96.0 & 200 \\
\hline \multicolumn{4}{|l|}{ Education } \\
\hline Illiterate & 81 & 40.5 & 200 \\
\hline Can read only & 31 & 15.5 & 200 \\
\hline Can read \& write & 71 & 35.5 & 200 \\
\hline Primary & 7 & 3.5 & 200 \\
\hline Middle education & 3 & 1.5 & 200 \\
\hline High school & 5 & 2.5 & 200 \\
\hline Graduate & 2 & 1.0 & 200 \\
\hline \multicolumn{4}{|l|}{ Occupation } \\
\hline Farmer cum rearer & 2 & 1.0 & 200 \\
\hline Trader cum rearer & 3 & 1.5 & 200 \\
\hline Camel rearer & 194 & 97.0 & 200 \\
\hline Other & 1 & 0.5 & 200 \\
\hline \multicolumn{4}{|l|}{ Material possessions } \\
\hline Traditional & 144 & 72.0 & 200 \\
\hline Modern & 55 & 27.5 & 200 \\
\hline Luxurious & 1 & 0.5 & 200 \\
\hline \multicolumn{4}{|l|}{ Housing } \\
\hline Hut & 2 & 1.0 & 200 \\
\hline Kutcha house & 17 & 8.5 & 200 \\
\hline Mixed house & 85 & 42.5 & 200 \\
\hline Pukka house & 96 & 48.0 & 200 \\
\hline
\end{tabular}




\begin{tabular}{|c|c|c|c|}
\hline Wood & 70 & 35.0 & 200 \\
\hline Gas & 60 & 30.0 & 200 \\
\hline Kerosene & 20 & 10.0 & 200 \\
\hline Electricity & 3 & 1.5 & 200 \\
\hline More than one & 47 & 23.5 & 200 \\
\hline \multicolumn{4}{|l|}{ Use of Camel milk } \\
\hline Domestic consumption & 90 & 45.0 & 200 \\
\hline Sale & 53 & 26.5 & 200 \\
\hline Both & 57 & 28.5 & 200 \\
\hline \multicolumn{4}{|c|}{ Income from Camel Husbandry } \\
\hline Camel milk & 90 & 45.0 & 200 \\
\hline By-products (wool etc.) & 59 & 29.5 & 200 \\
\hline Both & 51 & 25.5 & 200 \\
\hline \multicolumn{4}{|l|}{ Social Participation } \\
\hline Member of 1 organization & 165 & 82.5 & 200 \\
\hline Office bearer & 30 & 15.0 & 200 \\
\hline Member of $>1$ organization & 3 & 1.5 & 200 \\
\hline Public leader & 2 & 1.0 & 200 \\
\hline \multicolumn{4}{|l|}{ Savings/investment } \\
\hline Capital & 49 & 24.5 & 200 \\
\hline Cash & 84 & 42.0 & 200 \\
\hline Both & 67 & 33.5 & 200 \\
\hline \multicolumn{4}{|l|}{ Saving instruments } \\
\hline Saving account & 128 & 64.0 & 200 \\
\hline Fixed deposits & 21 & 10.5 & 200 \\
\hline SHG & 26 & 13.0 & 200 \\
\hline Microfinance & 25 & 12.5 & 200 \\
\hline \multicolumn{4}{|c|}{$\begin{array}{l}\text { Visit at NRCC (ICAR-National } \\
\text { Research Centre on Camel) }\end{array}$} \\
\hline Yes & 131 & 65.5 & 200 \\
\hline No & 69 & 34.5 & 200 \\
\hline
\end{tabular}

Source: Author's own computation based on field data 2019 


\section{Results and discussion}

The Socio-economic aspects of camel rearers are presented in Table.1. Among social classes majority of sample belongs to Rebari, followed by Dewasi, Raika, Muslim and Bishnoi. The population belongs 96 per cent to joint family type and four per cent belongs to nuclear family type. This shows that generally 'Raikas' live in joint families in the villages and taking care of camels. Majority of camel rearers were illiterate (40.5 per cent) followed by respondents who can read and write (35.5 per cent), respondents who can read only (15.5 per cent), respondents educated up to primary (3.5 per cent), respondents studied high school (2.5 per cent), respondents studied middle education (1.5 per cent) and respondents studied graduation(1 per cent).

The current generation is going for higher education while the past generation was illiterate, and they can read and write only. Majority of the population belongs to camel rearers followed by trader cum rearers and farmer cum rearers.Majority of the population were having traditional household necessities followed by modern and luxurious household possessions.

The material possessions had been categorized in three categories. The traditional category is based on camel rearer living in remote locations with basic necessities, modern category on the basis of camel rearers owning improved living equipment's like sewing machine, telephone, LPG and luxurious category on the basis of camel rearers owning television, laptop, generator, washing machine, refrigerator, any four-wheeler.

The 48 per cent of respondents own pukka house, 42.5 per cent mixed house, 8.5 per cent kutcha house and 1 per cent hut.23.5 per cent camel rearers were using more than one type of cooking fuel and rests of the camel rears were dependent on one kind of cooking fuel. Majority of the respondents were using gas cylinders for cooking purpose followed by wood, kerosene and electricity. Majority of camel rearers were using camel milk for domestic consumption. 26.5 per cent of sample was using camel milk for sale and 28.5 per cent of the respondents were using camel milk for both purposes. Majority of the income from camel husbandry comes from selling camel milk (70.5) per cent followed by selling of by-products mainly wool (29.5) per cent.

Majority of the respondents stands member of one organization 82.5 per cent followed by 15 per cent office bearer, 1.5 per cent member of $>1$ organization and 1 per cent wider public leader. Camel milk marketing is an emerging field so the majority of the savings/investment by camel rearers was cash 42 per cent followed by capital 24.5 per cent and both of these 33.5 per cent.

Savings instruments of the household majority were using saving account 64 per cent followed by SHG with 13 per cent, microfinance with 12.5 per cent and fixed deposits (in post office) with 10.5 per cent. Microfinance is basically a fund created by small savings of group members. Rearers form group and accumulate small savings at regular intervals to create a fund which is governed by body selected by group members.

The group members can take loan from microfinance funds on nominal interest and earns interest on his savings. National Research Centre on Camel, Bikaner had played an important role in the growth of camel milk. Out of total, 65.5 per cent camel rearers had been benefited in terms of training, extension and 34.5 per cent did not consult with NRCC. 
Table. 2 Constraints faced by Camel Rearers in Rajasthan

\begin{tabular}{|c|c|c|}
\hline Parameter & $\begin{array}{l}\mathrm{RBQ} \\
\text { mean }\end{array}$ & Rank \\
\hline There is no organized market for selling the produce & 92.40 & 1 \\
\hline $\begin{array}{l}\text { The Lengthy procedures for getting credit from government institutions for } \\
\text { marketing purpose }\end{array}$ & 86.80 & 2 \\
\hline Lack of knowledge regarding the benefits of camel milk & 84.60 & 3 \\
\hline The logistics cost for camel milk is high & 72.30 & 4 \\
\hline There is a need of regulatory authority & 70.10 & 5 \\
\hline There is a need of proper pricing criteria special for camel milk & 64.40 & 6 \\
\hline There is a need of processing units & 54.60 & 7 \\
\hline It requires skilled labour & 46.20 & 8 \\
\hline There is a high cost of labour in rearing camels & 41.00 & 9 \\
\hline There is a need of awareness campaigns & 32.00 & 10 \\
\hline $\begin{array}{l}\text { There is a need of government schemes/programmes for supporting the } \\
\text { camel rearing }\end{array}$ & 25.70 & 11 \\
\hline There is a need of increasing veterinary/extension services & 18.90 & 12 \\
\hline Unawareness regarding the registration procedures & 14.40 & 13 \\
\hline
\end{tabular}

Source: Author's own computation based on field data 2019

The major constraints faced by the camel rearers in the study area are identified and ranked based on the basis of RBQ technique. The major problems are no organized market for selling the produce(92.40), lengthy procedures for getting credit from government institutions for marketing purpose (86.80), lack of knowledge regarding the benefits of camel milk (84.60), logistics cost for camel milk is high (72.30).

And there is a need of regulatory authority (70.10), there is a need of proper pricing criteria special for camel milk (64.40), there is a need of processing units (54.60), requires skilled labour (46.20), there is a high cost of labour in rearing camels (41.00), there is a need of awareness campaigns (32.00).

Also, there is a need of government schemes/programmes for supporting the camel rearing (25.70), there is a need of increasing veterinary/extension services (18.90) and unawareness regarding the registration procedures (14.40). 


\section{Future work}

As this research was focused on developing entrepreneurship only in Rajasthan state, it requires more research for formulating the supply chain of camel milk from the remote locations of Rajasthan to rest of the country.The engineering infrastructure required to support camel milk processing at larger scale requires a series of research and innovation.

\section{References}

Agrawal, R P., Singh, G, Nayak, K C., Kochar, D K., Sharma, R C., Beniwal, R., and Gupta, R. 2004. Prevalence of diabetes in camel milk consuming 'RAICA'Rural Community of northwest Rajasthan. International Journal of Diabetes in Developing Countries.24: 109-14.

Agrawal, R P., Beniwal, R., Sharma, S., Kochar, D. K., Tuteja, F. C., Ghorui, S. K., and Sahani, M. S. 2005. Effect of raw camel milk in type 1 diabetic patients: A 1-year randomized study. Journal of Camel Practice and Research. 12(1): 27.

Agrawal, R. P., Beniwal, R., Kochar, D. K., Tuteja, F. C., Ghorui, S. K., Sahani, M. S., and Sharma, S. 2005. Camel milk as an adjunct to insulin therapy improves long-term glycemic control and reduction in doses of insulin in patients with type-1 diabetes: A 1-year randomized controlled trial. Diabetes research and clinical practice. 68(2): 176-177.

BAHS (2012). Basic Animal Husbandry Statistics, retrieved from http//www.dahd.nic.in on 1 February 2017.

FAOSTAT, (2015).Animal Production Yearbook, Food \& Agricultural Organization, Rome, Italy.https:faostat3.fao.org/download/Q/ QA/E (Accessed 8 February 2017)

Livestock Census Report (2012).19th Livestock Census-2012 retrieved from http://dahd.nic.in/sites/default/files/Live stock\%20\%205.pdf on 2 February 2017.

Meena, S., Rajput, Y. S., \& Sharma, R. (2014). Comparative fat digestibility of goat, camel, cow and buffalo milk. International Dairy Journal. 35(2): 153-156.

Raghvendar S, Shukla S, Sahani M S (2004). Prospects for adding value to camel milk in India. In: International conference on serving the camel and peoples' livelihoods: proceedings of an international conference held on 23-25 November 2004 in Sadri. Lokhit PashuPalak Sansthan, Sadri, Rajasthan, India, p38

www.pastoralpeoples.org/docs/camel_c onf_proc.pdf

Singh, R., Mal, G., Kumar, D., Patil, N. V., and Pathak, K. M. L. 2017. Camel milk: an important natural adjuvant. Agricultural Research. 6(4): 327-340.

\section{How to cite this article:}

Gurbir Singh, Amita Sharma and Raghvendar Singh. 2020. A Study on Socio-Economic Status and Problems faced by Camel Rearers in Rajasthan State of India. Int.J.Curr.Microbiol.App.Sci. 9(02): 316-322. doi: https://doi.org/10.20546/ijcmas.2020.902.040 